Journal of Engineering and Applied Sciences 14 (Special Issue 9): 10511-10516, 2019

ISSN: 1816-949X

(C) Medwell Journals, 2019

\title{
Debt Policy Analysis of Czech Companies
}

\author{
Lenka Stryckova \\ Technical University of Liberec, Faculty of Economics, Liberec, Czech Republic
}

\begin{abstract}
The attitude of companies towards the use of debt depends on many factors that can be generally called corporate debt policy. This study deals with the debt policy of companies in the Czech Republic, focusing on the factors affecting the appropriate amount of debt and their debt policy in general. The aim of this contribution is to reveal dominant factors affecting companies in their debt policy decisions and to analyze the possible impact of selected classifying factors on firm's responses. The findings of this study are based on a questionnaire survey and the subsequent statistical analysis of responses. The most important factors affecting the appropriate amount of debt proved to be financial flexibility and the volatility of earnings and cash flows. For deciding on debt policy, the most important factor was insufficiency of internal funds. Statistical analysis revealed several differences in response to debt-policy questions according to the legal form of business, the industrial sector, the company size and the origin of capital.
\end{abstract}

$\underline{\text { Key words: Debt policy, capital structure determinants, company, classifying, appropriate, industrial sector }}$

\section{INTRODUCTION}

Debt financing serves as important source of finance in case of own capital shortage. Most companies use debt sources to a greater or lesser extent. The attitude of companies towards the use of debt depends on many factors that can be generally called corporate debt policy.

The use of debt sources brings a company several benefits as the company can consider more investment opportunities that can increase the firm's value. At the same time, excessive use of debt may cause serious problems to the company connected with higher risk for the investors.

The debt policy of companies has undergone substantial development, since, the first theories concerning debt financing and capital structure were published in the fifties of the last century. In general, theories of capital structure can be divided into static and dynamic ones. The basic static theories of corporate capital structure include the theory of optimal capital structure, based on Miller and Modigliani's (1958) theory on the impact of taxes and the costs of financial distress, and the trade-off theory of capital structure. The most widespread and most respected theory of corporate capital structure is considered to be the theory of optimal capital structure which is based on the assumption that the use of debt in corporate financing leads to the reduction of the average cost of total capital; but it happens only up to a certain level of debt: when exceeded, the average cost of capital starts rising again. On the other hand, the dynamic theories do not seek an optimal capital structure but provide a certain preferential hierarchy of financial resources of a company (the pecking order theory).
Despite fundamental theoretical developments in recent years, the general understanding of corporate capital structure remains incomplete. The background of corporate debt policy has been the subject of intensive theoretical modelling and empirical examination over the years. Recent studies focused on the Czech environment were performed by Landa and Martinovicova (2010), Hrdy, Aulova and Hlavsa (2013) and Prasilova (2012).

This study deals with the capital structure of companies in the Czech Republic, focusing on their debt policy and its determinants. The aim of this contribution is to reveal dominant factors affecting companies in their debt policy decisions and to analyze the possible impact of the classifying factor (legal form of business, industrial sector, company size, origin of capital) on the responses.

\section{MATERIALS AND METHODS}

The study includes the results of an empirical investigation based on a questionnaire focused on the corporate debt policy of the Czech companies. The questionnaire was distributed by students of the Faculty of Economics to 220 CFOs of companies across the Czech Republic. Via personal interviews, students managed to get 197 completed questionnaires, of which about 165 were completed properly. The questionnaire contained questions focused on the evaluation of corporate performance from the accounting and financial point of view. In order to disclose the firm's debt policy, it also contained questions focused on corporate debt strategy adopted from the questionnaire that was created by Graham and Harvey (2001) (questions 12 and 13 in particular; question 12 had 15 subparts, question 13 had 9 subparts). The evaluation of the data was carried out using the methods of descriptive statistics. 


\section{RESULTS AND DISCUSSION}

Table 1 and Fig. 1 illustrate the survey responses to the question: "What factors affect how you choose the appropriate amount of debt for your firm?”. All figures in this study are based on the 95\% confidence intervals of the average values of variables. The most important factors affecting the appropriate amount of debt of respondents proved to be: " $\mathrm{g}$ ) financial flexibility", followed by "h) the volatility of our earnings and cash flows" and "n) we restrict our borrowing, so that, profits from new/future projects can be captured fully by shareholders and do not have to be paid out as interest to debtholders". A distinctly low impact was found for the variables: " $\mathrm{m}$ ) to ensure that upper management works hard and efficiently, we issue sufficient debt to make sure that a large portion of our cash flow is committed to interest payments", " $\mathrm{j}$ ) we try to have enough debt that we are not an attractive takeover target" ( 0.38$)$ and "l) a high debt ratio helps us bargain for concessions from our employees".

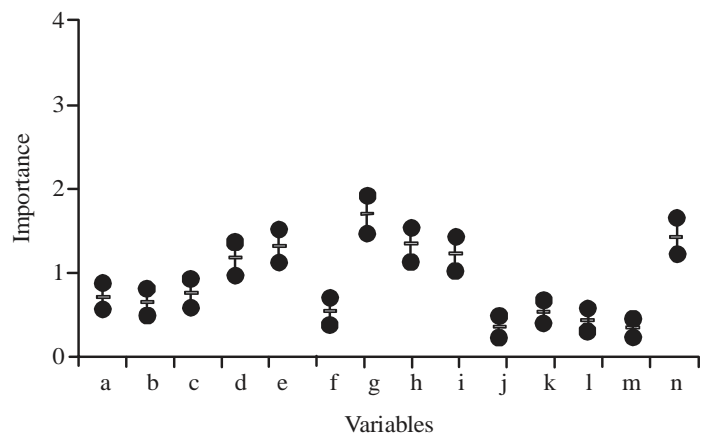

Fig. 1: Factors affecting appropriate amount of debt
Analysis of variance ANOVA was used to assess the impact of business legal form, industrial sector, company size and origin of capital on the responses. When the value of the significance level $\alpha$ is $\leq 0.05$, the hypothesis that the variable exerts no influence can be rejected. If $\alpha$ is $\geq 0.05$, it is not possible to reject the null effect of a variable Table 2 and Fig. 2 and 3.

The variables by means of which ANOVA identified the impact of the classifying factor (legal form of business, industrial sector, company size, origin of capital) on the composition of responses $(\alpha \leq 0.05)$ were further analyzed to verify this impact. The Wilcoxon signed-rank test was used for the null hypothesis verification $\left(\mathrm{H}_{0} \mu_{1}=\mu_{2}\right)$.

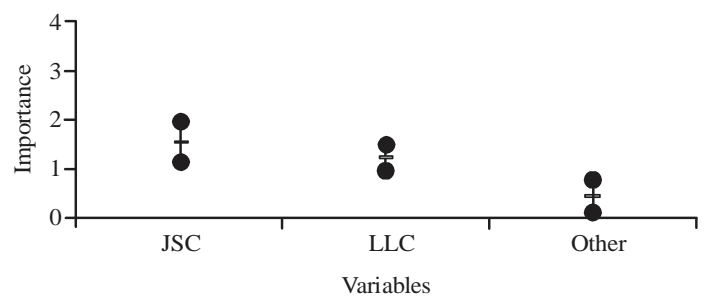

Fig. 2: Impact of legal form of business on the importance of variable "d"

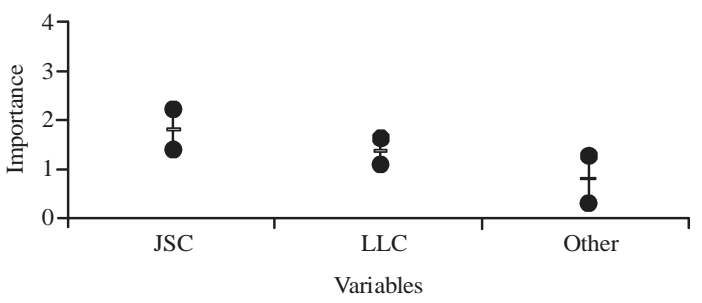

Fig. 3: Impact of legal form of business on the importance of variable "h"

Table 1: Importance of variables: factors affecting appropriate amount of debt

\begin{tabular}{|c|c|c|c|c|c|c|c|c|}
\hline Variable & $\mathrm{n}$ & Mean & StD & Min* & Max* & Med & Min & $\overline{\mathrm{Max}}$ \\
\hline a) & 169 & 0.7 & 1.01 & 0.6 & 0.9 & 0 & 0 & 4 \\
\hline b) & 167 & 0.7 & 1.03 & 0.5 & 0.8 & 0 & 0 & 4 \\
\hline c) & 168 & 0.8 & 1.13 & 0.6 & 0.9 & 0 & 0 & 4 \\
\hline d) & 167 & 1.2 & 1.29 & 1.0 & 1.4 & 1 & 0 & 4 \\
\hline e) & 168 & 1.3 & 1.33 & 1.1 & 1.5 & 1 & 0 & 4 \\
\hline f) & 168 & 0.6 & 1.07 & 0.4 & 0.7 & 0 & 0 & 4 \\
\hline g) & 168 & 1.7 & 1.51 & 1.5 & 1.9 & 2 & 0 & 4 \\
\hline h) & 169 & 1.4 & 1.34 & 1.2 & 1.6 & 1 & 0 & 4 \\
\hline i) & 167 & 1.2 & 1.33 & 1.0 & 1.4 & 1 & 0 & 4 \\
\hline j) & 168 & 0.4 & 0.86 & 0.2 & 0.5 & 0 & 0 & 4 \\
\hline k) & 168 & 0.5 & 0.92 & 0.4 & 0.7 & 0 & 0 & 4 \\
\hline l) & 168 & 0.5 & 0.89 & 0.3 & 0.6 & 0 & 0 & 4 \\
\hline m) & 165 & 0.4 & 0.67 & 0.3 & 0.5 & 0 & 0 & 4 \\
\hline n) & 166 & 1.4 & 1.42 & 1.2 & 1.7 & 1 & 0 & 4 \\
\hline
\end{tabular}

*95\% Confidence interval $\mu$. Responses in likert scale 0-4; Variables: a) The tax advantage of interest deductibility; b) The potential costs of bankruptcy, near-bankruptcy or financial distress; c) The debt levels of other firms in our industry; d) Our credit rating (as assigned by rating agencies) e) The transactions costs and fees for issuing debt; f) The personal tax cost our investors face when they receive interest income; g) Financial flexibility (we restrict debt, so, we have enough internal funds available to pursue new projects when they come along); h) The volatility of our earnings and cash flows; i) We limit debt, so, our customers/suppliers are not worried about our firm going out of business; j) We try to have enough debt that we are not an attractive takeover target; $\mathrm{k}$ ) If we issue debt our competitors know that we are very unlikely to reduce our output; l) A high debt ratio helps us bargain for concessions from our employees; $m$ ) To ensure that upper management works hard and efficiently, we issue sufficient debt to make sure that a large portion of our cash flow is committed to interest payments; n) We restrict our borrowing, so that, profits from new/future projects can be captured fully by shareholders and do not have to be paid out as interest to debtholders 


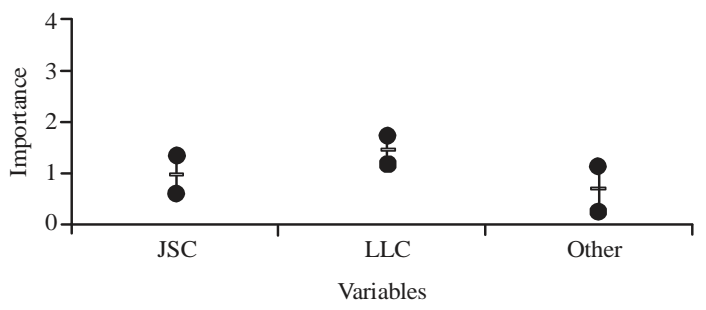

Fig. 4: Impact of legal form of business on the importance of variable "i”

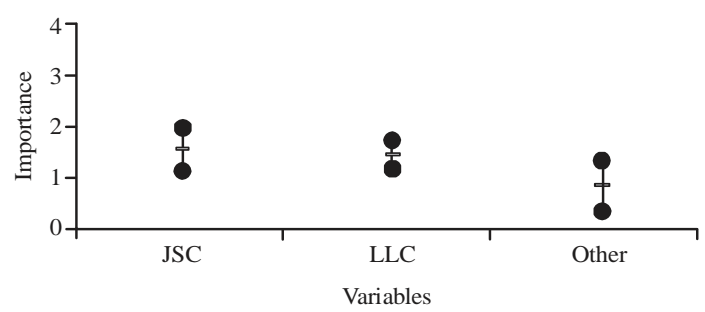

Fig. 5: Impact of legal form of business on the importance of variable " $n$ "

The average value analysis of the importance of variables "d) our credit rating" and "h) volatility of our earnings and cash flows" according to the legal form of business confirmed ANOVA conclusions. Statistically significant differences were found in the average values of importance between legal forms of Joint-Stock Company (JSC) and other forms as was demonstrated by the Wilcoxon signed-rank test of average values $(\mathrm{p} \leq 0.0001)$ (Fig. 4).

The average value analysis of the importance of variable "i) we limit debt so our customers/suppliers are not worried about our firm going out of business" according to the legal form of business again confirmed the ANOVA conclusion. Statistically significant differences were found in the average values of importance between the legal form of a Limited Liability Company (LLC) and other forms as demonstrated by the Wilcoxon signed-rank test of average values $(\mathrm{p} \leq 0.0008)$ (Fig. 5).

The average value analysis of the importance of variable "n) We restrict our borrowing, so that, profits from new/future projects can be captured fully by shareholders and do not have to be paid out as interest to debtholders" according to the legal form of business confirmed the ANOVA conclusions. Statistically significant differences were found in the average values of importance between the legal form of a Joint-Stock Company (JSC) and other forms as demonstrated by the Wilcoxon signed-rank test of average values $(\mathrm{p} \leq 0.012)$ (Fig. 6.)

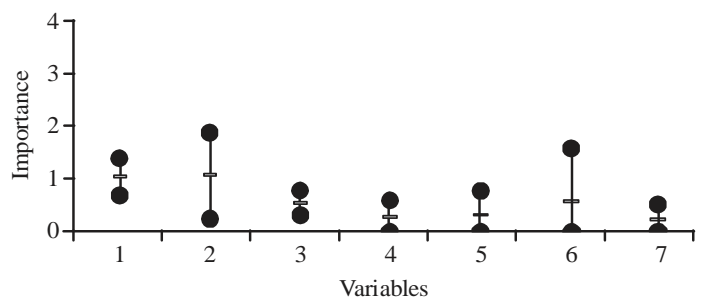

Fig. 6: Impact of industry on the importance of variable "b" (Industry: 1-retail and wholesale, 2-Mining, construction, 3-Manufacturing, 4-Transport/ energy, 5-Communications/media, 6-Bank/ finance/insurance, 7-Tech (software/biotech/etc))

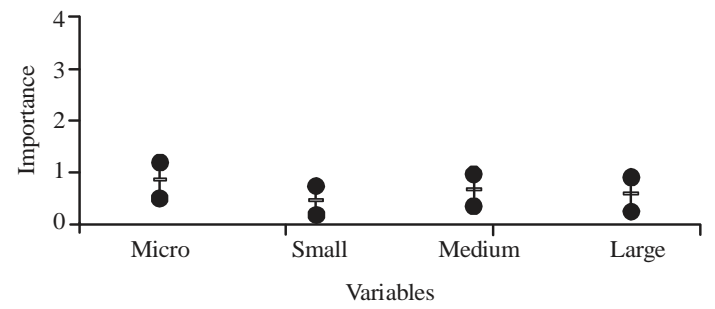

Fig. 7: Impact of company size on the importance of variable "d"

The average value analysis of the importance of variable "b) the potential costs of bankruptcy, near-bankruptcy or financial distress" according to industrial sector confirmed the ANOVA conclusions. The average value of importance in the sector 1-Retail and Wholesale is statistically more significant than in industries 3-Manufacturing, 4-Transport/Energy and 7-Tech $\left(\mathrm{p}-{ }_{\max } \leq 0.02\right)$. The difference in the mean values between industry types 1-Retail and Wholesale and 5-Communications/Media is also statistically important but the conclusion is on the edge of acceptability $(\mathrm{p} \leq 0.048)$. Therefore, the conservative conclusion of a statistically uncertain relationship is more suitable here (Fig. 7).

The average value analysis of the importance of variable "d) our credit rating" according to company size didn't confirm the ANOVA conclusions. No statistically significant difference was found between the average values of importance of variable "d" according to company size $\left(\mathrm{p}_{\min } \leq 0.187\right)$. It is necessary to take into account the fact that ANOVA predicted results at the significance level of 0.048 which is a statistically indefinite conclusion. Table 3 and Fig. 8 illustrate responses to the question: "What other factors affect your firm's debt policy?"

It is evident in Fig. 8 that the most significant other factor affecting a firm's debt policy is expressed by the statement "a) we issue debt when our recent 
J. Eng. Applied Sci., 14 (Special Issue 9): 10511-10516, 2019

Table 2: ANOVA: factors affecting appropriate amount of debt

\begin{tabular}{|c|c|c|c|c|c|c|c|c|}
\hline \multirow[b]{2}{*}{$\underline{\text { Variables }}$} & \multicolumn{2}{|c|}{ Legal Form } & \multicolumn{2}{|c|}{ Industry } & \multicolumn{2}{|l|}{ Size } & \multicolumn{2}{|c|}{ Foreign capital } \\
\hline & $\mathrm{F}$ & $\alpha$ & $\mathrm{F}$ & $\alpha$ & $\mathrm{F}$ & $\alpha$ & $\mathrm{F}$ & $\alpha$ \\
\hline $\bar{a}$ & 0.604 & 0.547 & 1.4250 & 0.2340 & 1.0760 & 0.312 & 0.729 & 0.395 \\
\hline b & 0.957 & 0.386 & 12.512 & 0.0005 & 1.0010 & 0.317 & 1.436 & 0.233 \\
\hline c & 2.125 & 0.127 & 0.0580 & 0.8100 & 0.8522 & 0.357 & 1.610 & 0.206 \\
\hline d & 6.879 & 0.001 & 1.7090 & 0.1930 & 3.9850 & 0.048 & 2.493 & 0.116 \\
\hline e & 2.617 & 0.076 & 1.0610 & 0.3040 & 0.9800 & 0.324 & 3.324 & 0.070 \\
\hline $\mathrm{f}$ & 2.455 & 0.089 & 0.0800 & 0.7740 & 1.1380 & 0.288 & 0.897 & 0.345 \\
\hline g & 0.711 & 0.493 & 0.2570 & 0.6130 & 1.9220 & 0.167 & 0.361 & 0.549 \\
\hline h & 4.951 & 0.008 & 0.1260 & 0.7230 & 0.2920 & 0.590 & 0.834 & 0.363 \\
\hline i & 4.538 & 0.012 & 0.2740 & 0.6030 & 1.8400 & 0.177 & 0.132 & 0.717 \\
\hline j & 1.915 & 0.151 & 0.5620 & 0.4540 & 0.3060 & 0.581 & 0.141 & 0.708 \\
\hline $\mathrm{k}$ & 2.666 & 0.073 & 0.7350 & 0.3930 & 0.1100 & 0.740 & 0.249 & 0.619 \\
\hline 1 & 2.500 & 0.085 & 1.0100 & 0.3160 & 0.0001 & 0.992 & 0.430 & 0.513 \\
\hline $\mathrm{m}$ & 1.298 & 0.276 & 2.0250 & 0.1570 & 0.3910 & 0.532 & 0.246 & 0.621 \\
\hline$\underline{\mathrm{n}}$ & 3.085 & 0.048 & 0.0150 & 0.9030 & 0.0010 & 0.973 & 2.942 & 0.089 \\
\hline
\end{tabular}

Table 3: Importance of variables: other factors affecting a firm's debt policy

\begin{tabular}{lcccccccc}
\hline Variable & $\mathrm{n}$ & Mean & StD & Min* & Max* & Med & Min & Max \\
\hline a) & 173 & 2.5 & 1.49 & 2.3 & 2.8 & 3 & 0 & 4 \\
b) & 168 & 0.4 & 0.84 & 0.2 & 0.5 & 0 & 0 \\
c) & 168 & 1.0 & 1.19 & 0.8 & 1.2 & 1 & 0 \\
d) & 167 & 0.4 & 0.74 & 0.2 & 0.5 & 0 & 0 \\
e) & 168 & 0.9 & 1.22 & 0.7 & 1.1 & 0 & 0 \\
f) & 167 & 0.4 & 0.82 & 0.3 & 0.6 & 0 & 0 & 4 \\
g) & 162 & 0.3 & 0.67 & 0.1 & 0.4 & 0 & 0 & 4 \\
h) & 167 & 0.6 & 1.01 & 0.5 & 0.8 & 0 & 0 \\
\hline
\end{tabular}

*95\% Confidence interval $\mu$. Responses in likert scale 0-4; Variables: a) We issue debt when our recent profits (internal funds) are not sufficient to fund our activities; b) Using debt gives investors a better impression of our firm's prospects than issuing stock; c) We issue debt when interest rates are particularly low; d) We use debt when our equity is undervalued by the market; e) We delay issuing debt because of transactions costs and fees f) We delay retiring debt because of recapitalization costs and fees; g) Changes in the price of our common stock; h) We issue debt when we have accumulated substantial profits

Table 4: ANOVA: other factors affecting a firm's debt policy

\begin{tabular}{|c|c|c|c|c|c|c|c|c|}
\hline \multirow[b]{2}{*}{ Variables } & \multicolumn{2}{|c|}{ Legal Form } & \multicolumn{2}{|c|}{ Industry } & \multicolumn{2}{|l|}{ Size } & \multicolumn{2}{|c|}{ Foreign capital } \\
\hline & $\mathrm{F}$ & $\mathrm{CI}$ & $\mathrm{F}$ & $\mathrm{CI}$ & $\mathrm{F}$ & $\mathrm{CI}$ & $\mathrm{F}$ & $\mathrm{CI}$ \\
\hline $\mathrm{a}$ & 4.540 & 0.012 & 0.099 & 0.754 & 0.845 & 0.359 & 0.001 & 0.975 \\
\hline b & 1.860 & 0.159 & 0.548 & 0.460 & 0.582 & 0.447 & 0.624 & 0.431 \\
\hline c & 4.420 & 0.013 & 0.963 & 0.328 & 2.135 & 0.146 & 1.198 & 0.275 \\
\hline $\mathrm{d}$ & 2.199 & 0.114 & 0.154 & 0.696 & 2.781 & 0.097 & 5.389 & 0.021 \\
\hline e & 0.983 & 0.376 & 2.614 & 0.108 & 0.002 & 0.966 & 0.433 & 0.511 \\
\hline $\mathrm{f}$ & 2.396 & 0.094 & 0.062 & 0.804 & 0.000 & 0.987 & 0.842 & 0.360 \\
\hline g & 5.273 & 0.006 & 2.682 & 0.103 & 2.339 & 0.128 & 6.517 & 0.012 \\
\hline h & 2.471 & 0.088 & 3.827 & 0.052 & 0.028 & 0.867 & 0.333 & 0.565 \\
\hline
\end{tabular}

Bold values are significant

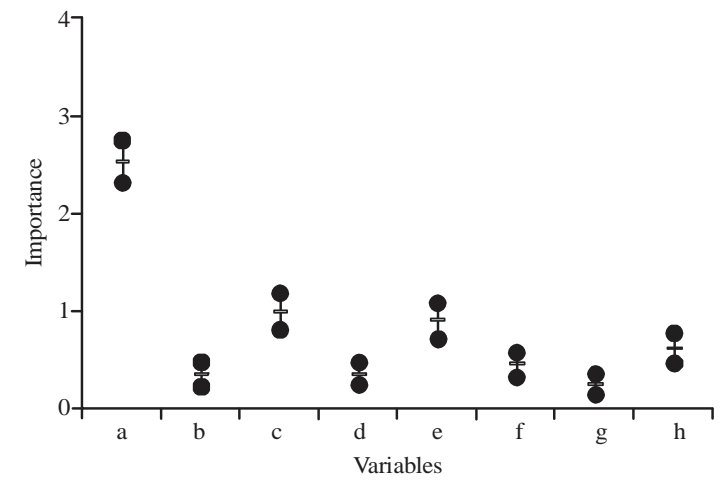

Fig. 8: Other factors affecting a firm’s debt policy profits (internal funds) are not sufficient to fund our activities". The analysis of variance ANOVA was used to assess the impact of business legal form, industrial sector, company size and origin of capital on responses to the question about other factors affecting a firm's debt policy Table 4 and Fig. 9.

The variables by means of which ANOVA identified the impact of the classifying factor on the composition of responses $(\alpha \leq 0.05)$ were further analyzed to verify this impact. The Wilcoxon signed-rank test was also used for the null hypothesis verification $\left(\mathrm{H}_{0} \mu_{1}=\mu_{2}\right)$.

The average value analysis of the importance of variable "a) we issue debt when our recent profits are not sufficient to fund our activities" according to the legal 


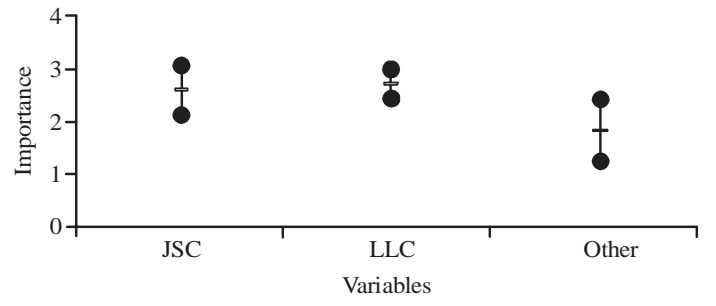

Fig. 9: Impact of legal form of business on the importance of variable "a”

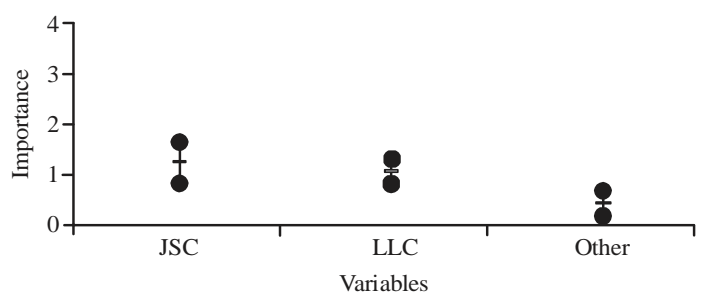

Fig. 10: Impact of legal form of business on the importance of variable "c"

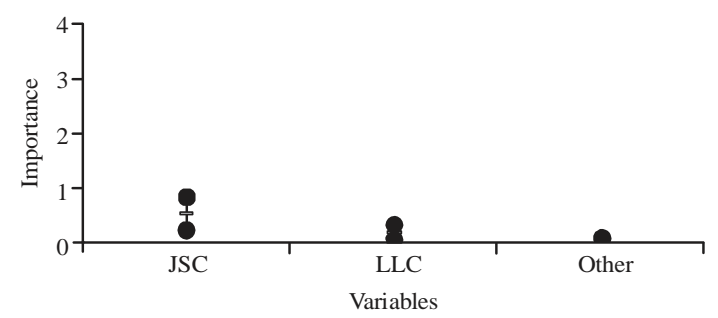

Fig. 11: Impact of legal form of business on the importance of variable " $g$ "

form of business confirmed the ANOVA conclusions. Statistically significant differences were found in the average values of importance between the legal form of Limited Liability Company (LLC) and other forms as was demonstrated by the Wilcoxon signed-rank test of average values $(\mathrm{p} \leq 0.007)$. A statistically indefinite relationship was found between the legal form of JSC and others $(\mathrm{p} \leq 0.049)$ (Fig. 10).

The ANOVA conclusions were confirmed; statistically significant differences were found between the average values of importance of variable “c) we issue debt when interest rates are particularly low" for other legal forms of business and the remaining group of companies, comprising joint-stock and limited liability companies $\left(\mathrm{p}_{\max } \leq 0.02\right)$ (Fig. 11).

The ANOVA conclusions were also confirmed; statistically significant differences were found between the average values of importance of variable "g) changes in the price of our common stock" for other legal forms of business and joint-stock companies $\left(\mathrm{p}_{\max } \leq 0.002\right)$ (Fig. 12 and 13).

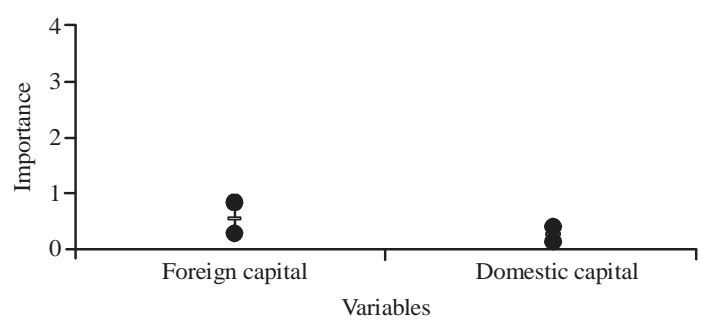

Fig. 12: Impact of capital origin on the importance of variable "d"

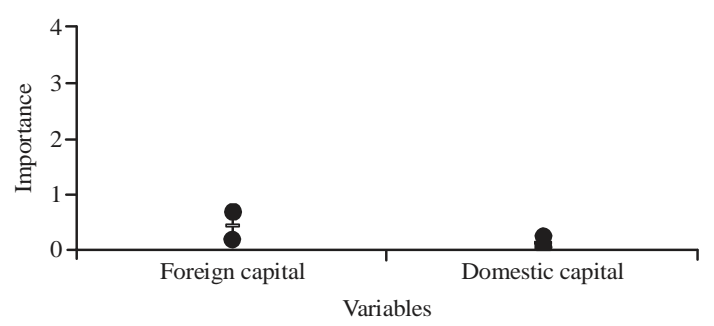

Fig. 13: Impact of capital origin on the importance of variable "g"

The conclusions of ANOVA were confirmed. The average values of importance of variables “d) we use debt when our equity is undervalued by the market" and "g) Changes in the price of our common stock" are statistically significantly different for companies owned by foreign capital in comparison to companies owned by domestic capital as demonstrated the Wilcoxon signed-rank test of average values $\left(\mathrm{p} \leq 0.027, \mathrm{p} \leq 2.2 \times 10^{-16}\right.$, respectively).

\section{CONCLUSION}

The study is based on empirical investigation in the Czech Republic and the use of some of the questions from the questionnaire created by Graham and Harvey focused on corporate debt policy.

The most important factors affecting the appropriate amount of debt of respondents proved to be financial flexibility, the volatility of earnings and cash flows and the respondent's efforts to restrict borrowing, so that, profits from new/future projects can be captured fully by shareholders and do not have to be paid out as interest to debtholders. For deciding on the debt policy, the most important factor was insufficiency of recent profits (internal funds).

Statistical analysis revealed several differences in responses to debt-policy questions according to the legal form of business, the industrial sector, the company size and the origin of capital (domestic or foreign). Statistically significant differences were found in the average values of importance of four 
factors affecting the appropriate amount of debt assessed according to the legal form of business, one factor according to the industrial sector and one factor according to the company size. No significant difference was found according to the capital origin in responses to question concerning the appropriate amount of debt, however, this does not apply to the other factors affecting a firm's debt policy where ANOVA identified two factors. Other statistically significant differences in the average values of importance of factors affecting firm's debt policy were dependent on the legal form of business (three factors specifically).

This research is intended to be expanded by cross-country comparison which will be enabled by the use of the same survey questions that (Graham and Harvey, 2001). Since, then, several other researchers from various countries have provided national data and cross-country comparisons.

\section{REFERENCES}

Aulova, R. and T. Hlavsa, 2013. Capital structure of agricultural businesses and its determinants. Agris Online Pap. Econ. Inf., 5: 23-36.

Graham, J.R. and C.R. Harvey, 2001. The theory and practice of corporate finance: Evidence from the field. J. Financial Econ., 60: 187-243.

Landa, M. and D. Martinovicova, 2010. Approaches to the assessment of changes in the capital structure of industries. J. Agric. Silviculturae Mendelianae Brno., 58: 259-267.

Modigliani, F. and M.H. Miller, 1958. The cost of capital, corporation finance and the theory of investment. Am. Econ. Rev., 48: 261-297.

Prasilova, P., 2012. [Determinants of capital structure of Czech enterprises (In Czech)]. EM. Econ. Manage., 15: 89-104. 